\title{
Potential of Crop Residues for Energy Production in Nepal
}

\author{
Narayan Prasad Adhikari ${ }^{1, *}$, Manfred Denich ${ }^{2}$ \\ ${ }^{1}$ Alternative Energy Promotion Center, Ministry of Energy, Water Resources and Irrigation, Government of Nepal, \\ Khumaltar, Lalitpur, Nepal \\ ${ }^{2}$ Center for Development Research, University of Bonn, Germany \\ Corresponding Email: narayan.aepc@gmail.com
}

\begin{abstract}
:
The study aims at assessing the availability of crop residues for energy production in lowland, hill and mountain districts of Nepal. Rice, wheat, maize, millet and barley are included in the study that is based upon two different household surveys: (i) interviews conducted in 240 households to obtain key information about practices of crop harvesting, (ii) determination of the quantity of the main crops, their residues and alternative uses of the latter conducted in 27 households. Apart from the foremost use as fodder, there are five major uses of crop residues: building material, burning on the field, mulching of the field, selling and energy generation. Despite the higher amount of crop residues in the lowland (954 kg dry matter per capita and year) than in the hill district (547 $\mathrm{kg}$ capita $\left.\mathrm{yr}^{-1}\right)$, the amount of crop residues used for energy generation higher in the hill $\left(207 \mathrm{~kg} \mathrm{capita}^{-1} \mathrm{yr}^{-1}\right)$ than in the lowland district (152 kg capita $\left.{ }^{-1} \mathrm{yr}^{-1}\right)$. In the mountain district, the crop residue production is $263 \mathrm{~kg}$ capita ${ }^{-1} \mathrm{yr}^{-1}$, of which $26 \mathrm{~kg}_{\text {capita }} \mathrm{yr}^{-1} \mathrm{are} \mathrm{used}^{-1}$ for energy generation. The annual per capita energy equivalent from crop residues in the lowland, hills and mountains are $2.49 \mathrm{GJ}$, $3.42 \mathrm{GJ}$ and $0.44 \mathrm{GJ}$ which represent $30 \%, 33 \%$ and $3 \%$, respectively, of the total annual cooking energy consumption.
\end{abstract}

Keywords: Biomass, Crop residues, Lowlands, Hills, Mountains

\section{Introduction}

Crop residues are all non-edible parts of a crop remaining aboveground in different stages from harvesting until final processing, i.e., residues in the field and of processed parts $[1,2]$. For instance, rice straw is an example of field residues whereas rice husks are the residues obtained after processing. Depending on the harvesting method, there are different forms of field and processed-based residues.

Presently, particularly in developing countries, a large part of the crop residues is either left in the field, which leads to carbon dioxide and methane emissions during decomposition, or they are burned in open areas with the release of gaseous emissions and carbon. Thus, both processes result in greenhouse gas (GHG) emissions [3]. From the perspective of soil nutrients and crop production, the decomposition of crop residues in the field has both positive and negative effects [4]. The positive effects are control of soil erosion, maintaining or increasing soil organic matter, improving water conservation and storage, adding to the pool of soil nutrients, and improving soil structure and crop yields $[5,6]$. Some researchers report that residues may have negative effects on crop production by increasing crop diseases $[7,8]$ or the need for extra nitrogen fertilizers during the decomposition process due to their very often wide $\mathrm{C} / \mathrm{N}$ ratio [9].
To combat the overriding challenges of climate change and energy insecurity, crop residues are considered as one of the potential alternative sources to meet the increasing demand of fossil fuel [3]. Apart from occasional estimations as part of studies assessing the potential for better maintaining agro-ecosystems or the scope for biomass energy production, statistics on the production of crop residues do not exist [10]. This may be because of their versatile and random uses [1]. Different approaches are available on the estimation of the gross and technical potential of crop residues for energy uses [11]. These estimates are based on the data of crop production using the Residue to Product ratio (RPR) ( [12]. The ratio refers to the weight of the residues available after processing a harvested crop to the weight of grain obtained from the same process [13]. Koopmans and Koppejan [2] reviewed the literature on RPR values for various crops. Based on different studies in various regions of the world, RPR values are recommended. However, the estimated value cannot be converted fully to energy generation, as the residues are utilized for different purposes such as fodder, building material, mulching, etc. depending upon type of crop residues and geographical region.

Many studies have evaluated the potential of the crop residues for energy generation at different scales ranging from local to global. Most of these studies are based on 
individual fractions to be utilized for energy generation considering their competitive uses. Because of the variation in the quantity of crop residues as fodder, in their evaluation of biomass potential in Serbia, Ilić et al. [14] estimate a potential of $50 \%$ of total crop residues for energy generation in large farming systems, but only $20 \%$ in small farming systems. Wang and Mendelsohn [15] assume that $15 \%$ of the crop residues need to be left in the field for maintaining soil nutrient levels in China. Depending on soil texture, the minimum quantity of straw recommended for covering the soil ranges from 1 to 2 tons ha $^{-1}$ to protect it from wind and water erosion in Canada [16]. The variation of uses of crop residues depends upon the type of residue along with socio-economic, ecological and topographical characteristics of the study area.

Nepal is a country dependent on agriculture, where more than $66 \%$ of the population are engaged in the agriculture sector, which contributes $33 \%$ of the gross domestic product [17]. The total arable area is 3.1 million ha (about $20 \%$ of total land area) with a cropping intensity ${ }^{1}$ of $183 \%$ [18]. Agricultural practices are based on mixed croplivestock production systems where livestock provides manure, draught power, milk and meat whereas crops are the sources for food and fodder [19].These systems provide a considerable source of energy through direct burning of dung and crop residues in the fuelwooddeficient lowland, whereas this is negligible in the hills and mountain areas due to the relatively higher abundance of fuelwood [20]. The proliferating dependency on imported fossil fuels in the country has raised serious concerns on finding alternative energy resources, and crop residues are being considered as one of the potential options. The annual production of cereal crop residues in Nepal for the period 2011/12 was estimated to be 24.2 million tons of dry matter[21]. WECS [20] estimates the theoretical national energy potential of crop residues to be about 234 million GJ, which is around $61 \%$ of the total energy consumption of the country in 2008/09.

No surveys exist on the potential uses of crop residues for energy generation in Nepal. It was revealed that one third (3.2 million tons) of total crop production of major crop residues are used as fuel [22]. The data base on the availability of crop residues is inadequate in the country [23]. Against this background, this study presents the analysis of the production and prevailing uses of crop residues to assess their potential for energy production. The five major cereal staple crops rice, maize, wheat, millet and barley are considered.

\section{Materials and Methods}

\subsection{Study areas}

Three different administrative districts were selected to represent the three main topographic regions of the country, the districts Bajhang, Lamjung and Morang represent mountains, hills and lowland, respectively (Figure 1).

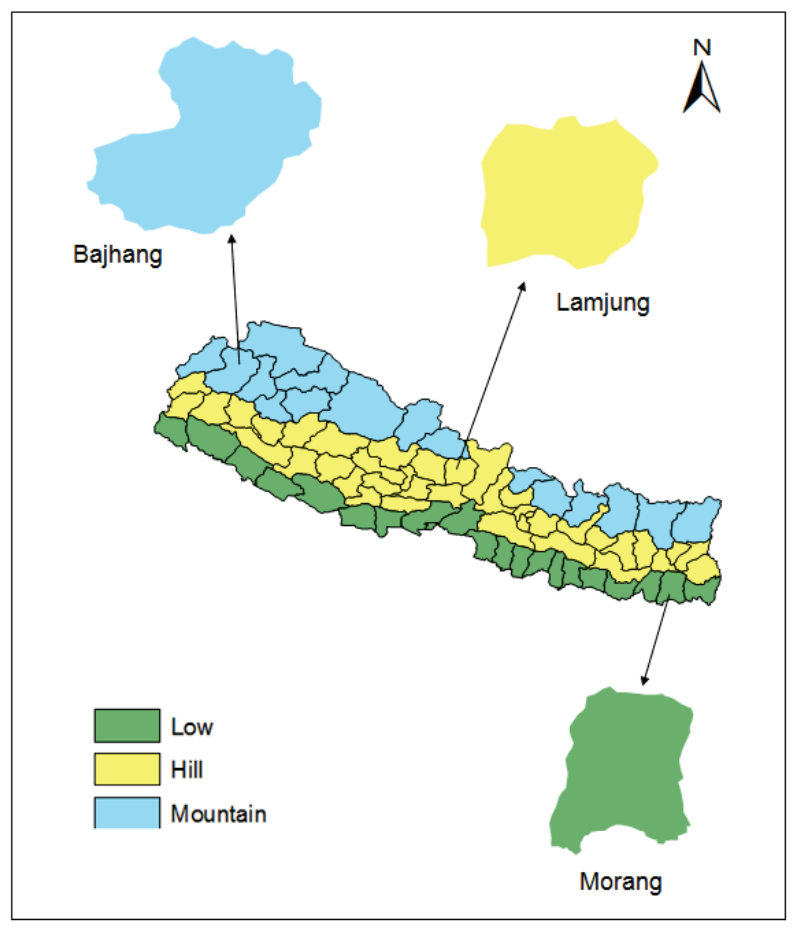

Figure 1: Map of Nepal showing the topographic regions and the study districts

\subsection{Cropping systems}

The agricultural lands in Nepal is generally characterized as 'Bariland' and 'Khetland', where 'Bariland' refers to non-irrigated rainfed terraces, and 'Khetland' to irrigated terraces. In general, upland rice, maize, wheat, millet and barley are grown in Bariland, whereas irrigated rice is mainly produced in Khetland. Furthermore, based on irrigation facility, Khetland may be either single or double irrigated. In double-irrigated Khetland rice is grown twice a year, one in the pre-monsoon and the other in the monsoon season [26,27].

Not only the crop yield but also the average size of cultivated land per holding is the highest in the lowland and the lowest in the mountain (Table 1). The share of rice is the highest in the lowland and hill districts and wheat in

\footnotetext{
${ }^{1}$ Cropping intensity refers to the proportion of cultivated land that is harvested. With more than one crop cycle in the year on the same area, crop intensity exceeds $100 \%$. [31]
} 
the mountain district. As barley production in the lowland and hill districts are negligible, crop residues for barley are not considered in these districts. The evaluation of crop residues in this study is based on production details of Table 1.

\subsection{Data collection}

The household located at village/municipal $\operatorname{ward}^{2}$ of a district is the ultimate sampling unit. First, the hills and mountain districts were stratified in three altitudinal zones (500 -1000 $\mathrm{m}$ above sea level, $1000-2000 \mathrm{~m}$ and above $2000 \mathrm{~m}$ ) and the lowland district in urban and rural zones. The wards in the municipality were treated as 'urban', and the remaining wards as 'rural'. The sample wards were then selected on the basis of probability proportional to size. Lists of all households were obtained from the ward offices and accordingly, 80 households from the sample wards in each district were selected on a random basis.

Household surveys were conducted in the three districts in two different ways. First, a standard household questionnaire was used for primary data collection. The demography, energy consumption, cropping pattern along with their management throughout the year and alternative uses of crop residues are major information. Secondly, in nine households from each district surveys have been conducted during the time of crop harvesting for quantifying each cereal crop and their residues in the field. The households were requested to separate all crop residues collected from a predefined sample area and to process them as usual. The sample areas varied from 50$100 \mathrm{~m}^{2}$. After crop processing, the grains and residues were weighed on an air-dry basis 25 to 30 days after harvesting based on which RPR values were calculated.

\subsection{Determination of energy potential}

The net potential of crop residues for energy production was evaluated by considering the quantity of crop residues used for burning in the field and prevailing uses of energy in the households. The unburned crop residues remaining in the field were not considered because of their essential role in maintaining soil nutrients (mulching) [28]. The quantity of crop residues for building material was evaluated on the basis of total quantity of material that was produced by crop residues in a year vis-à-vis the requirement of crop residues for the uses (mats, cushions, etc.). Because of the different energy-mix patterns in a household, it was difficult to quantify the amount of crop residues used for energy generation. Therefore, the annual energy consumption was estimated on the basis of the average daily weight of residues required for energy production. The quantity of livestock fodder was calculated by deducting the quantities used for building material and energy production from the total production. The information on the different uses of crop residues as obtained from the sample households was extrapolated to estimate each use of each crop residues at the district level.

While applying the RPR in order to evaluate the quantity of crop residues, the weight measurement was associated with the corresponding values of moisture content taken on a dry basis mode after oven-drying in the laboratory in the. The moisture content of the residues was determined at $105^{\circ} \mathrm{C}$.The average moisture content in three samples for each type of crop residue was considered as a basis for the analysis. A single representative RPR value (sample average) for a particular crop residue for all districts was used. The net heating values for the oven-dried crop residues were also determined.

Table 1: Cereal crop cultivation in the study districts (number of holdings, area and yield; CBS 2014)

\begin{tabular}{|c|c|c|c|c|c|c|c|c|c|}
\hline \multirow{2}{*}{ Crops - } & \multicolumn{3}{|c|}{ Lowland district } & \multicolumn{2}{|c|}{ Hills district } & & \multicolumn{3}{|c|}{ Mountain district } \\
\hline & of holdir & Area (ha) & eld (kg/) & of holdi & Area (ha & eld $(\mathrm{kg} / \mathrm{l}$ & ) No. of holdi & s Area (ha & ) Yield (kg/l \\
\hline Rice & 126,891 & 100,911 & 3,550 & 31,143 & 10,150 & 2,356 & 31,550 & 5,890 & 1,959 \\
\hline Maize & 43,659 & 12,895 & 3,000 & 31,385 & 7,854 & 2,316 & 18,696 & 1,778 & 1,555 \\
\hline Wheat & 48,467 & 37,346 & 2,396 & 2,541 & 197 & 1,970 & 31,902 & 7,412 & 1,462 \\
\hline Millet & 3,300 & 881 & 1,200 & 23,145 & 3,393 & 1,037 & 12,908 & 891 & 951 \\
\hline Barley - & & - & & & 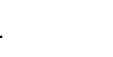 & & 12,772 & 1,019 & 899 \\
\hline
\end{tabular}

\footnotetext{
2 The study was conducted prior to 20 Sep 2015, when the local governance in Nepal was based upon two tiers, with Village Development Committee (VDC)/Municipality as the lower and District Development Committee (DDC) as the higher. The municipality had the same function in urban areas as the VDC in rural areas. Wards are the smallest units of either of the cases of VDC or municipality.
} 


\section{Results and Discussion}

The main use of crop residues is as livestock fodder, where all households tend to maximize the utilization of crop residues because a fodder deficit generally exists in all regions of the Nepal [29]. The residues from the five cereal crops consist of dedicated fodder and non-dedicated fodder residues. The crop residues utilized for livestock fodder represent dedicated fodder whereas those residues not applicable for livestock fodder are non-dedicated fodder residues. Except for maize stalks and maize cobs, all crop residues are dedicated fodder residues. Maize cobs were used by all households entirely for energy production, whereas apart from energy production, maize stalks were also burned in the field. The use of crop residues for building material was mainly for roofing of houses or livestock stalls or for cushions of different sizes. The use of dedicated residues for energy production was only in the lowland district and then by most of the households there.

\subsection{Residue to product ratio and moisture content}

The residue to product ratios (RPR) obtained from the survey are presented in Table 2 .

Table 2: Residue to product ratios (RPR) for different crops $(\mathrm{SD}=$ standard deviation $)$

\begin{tabular}{llllll}
\hline Crop residues & $\mathbf{N}$ & Mean & SD & Min & Max \\
\hline Rice husks & 18 & 0.36 & 0.14 & 0.08 & 0.79 \\
Rice straw & 18 & 1.97 & 0.57 & 1.08 & 3.33 \\
Wheat husks & 11 & 0.82 & 0.17 & 0.55 & 1.21 \\
Wheat straw & 11 & 1.46 & 0.39 & 0.98 & 2.12 \\
Maize stalks & 11 & 2.12 & 0.45 & 1.63 & 3.11 \\
Maize cobs & 11 & 0.28 & 0.05 & 0.18 & 0.37 \\
Maize ears & 11 & 0.29 & 0.06 & 0.22 & 0.38 \\
Millet husks & 11 & 0.14 & 0.04 & 0.06 & 0.23 \\
Millet straw & 11 & 1.89 & 0.53 & 1.22 & 3.20 \\
Barley straw & 9 & 1.52 & 0.43 & 1.01 & 2.11 \\
\hline
\end{tabular}

The following assumptions were made for the RPR analysis:

- Wheat husks refer to the mixture with the top parts of the straw, as this was the common method to provide fodder.

- Maize stalks did not include the top leaves, as these were immediately fed to the livestock as a green fodder during harvesting.

\subsection{Crop residues as building material}

Among various residues, the rice straw, wheat straw and barley straw were utilized for building material at household level (Table 3).

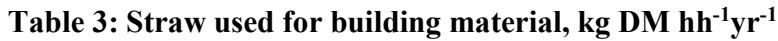
$(n=9$, the values in parentheses are standard deviations; DM=dry matter)

\begin{tabular}{llll}
\hline Type of straw & Lowland & Hills & Mountain \\
\hline Rice & $115(29)$ & $118(43)$ & $69(23)$ \\
\hline Wheat & $127(33)$ & $85(33)$ & $20(6)$ \\
\hline Barley & $5.5(2.4)$ & - & - \\
\hline
\end{tabular}

\subsection{Crop residues as energy uses}

The energy uses for non-dedicated fodder residue is simply estimated on the basis of total production of residues.

Table 4: Use of dedicated fodder residues for energy production in the lowland district (Values in parentheses are standard deviations)

\begin{tabular}{lll}
\hline \multirow{2}{*}{ Residue type } & \multicolumn{2}{l}{ Energy production } \\
\cline { 2 - 3 } & $\mathbf{N}$ & Weight $\left(\mathbf{k g} \mathbf{D M} \mathbf{h h}^{-\mathbf{1}} \mathbf{y r}^{-\mathbf{1}}\right)$ \\
\hline Rice straw & 9 & $232(119)$ \\
\hline Rice husks & 9 & $9(4)$ \\
\hline Wheat straw & 9 & $55(20)$ \\
\hline Wheat husks & 9 & $33(15)$ \\
\hline
\end{tabular}

As observed, the use of dedicated fodder residues for energy production only takes place in the lowland (Table 4). Because millet is only cultivated in the northern (hilly) part of the lowland district where there is a relatively better source of fuelwood, energy production from millet residues does not take place. Rice and wheat residues are extensively used by a large number of households in the southern part of the lowland. As obvious, the greater production of rice leads to greater use of their straw for energy production as compared to that of wheat.

\subsection{Quantification of crop residues for various uses}

The annual availability of different crop residues for various uses was estimated based on the overall crop production in each district (Table 1). The available amount of five major cereal crop residues in the lowland, hill and mountain districts was 877,820 t, 92,030 t and $51,810 \mathrm{t}$, respectively, of which the percentages of crop 
residues for energy generation were $16 \%, 38 \%$ and $10 \%$ in the lowland, hill and mountain districts, respectively (Table 5).

Table 5: Weight of available crop residues (t DM district ${ }^{-1}$ $\left.\mathrm{yr}^{-1}\right)$ in the study districts

\begin{tabular}{|c|c|c|c|c|}
\hline $\begin{array}{l}\text { Residue } \\
\text { type }\end{array}$ & $\begin{array}{l}\text { Total } \\
\text { production }\end{array}$ & $\begin{array}{l}\text { Energy } \\
\text { potential }\end{array}$ & $\begin{array}{l}\text { Building } \\
\text { material }\end{array}$ & $\begin{array}{l}\text { Livestock } \\
\text { fodder }\end{array}$ \\
\hline \multicolumn{5}{|l|}{ Lowland } \\
\hline Rice husks & 107,910 & 11,730 & 0 & 96,180 \\
\hline Rice straw & 528,230 & 49,560 & 15,847 & 462,823 \\
\hline Maize stalks & 53,010 & 53,010 & 0 & 0 \\
\hline Maize husks & 8,300 & 0 & 0 & 8,300 \\
\hline Maize cobs & 8,100 & 8,100 & 0 & 0 \\
\hline Wheat husks & 63,320 & 6,880 & 0 & 56,440 \\
\hline Wheat straw & 107,200 & 11,570 & 4,288 & 91,342 \\
\hline Millet husks & 120 & 0 & 0 & 120 \\
\hline Millet straw & 1,630 & 0 & 0 & 1,630 \\
\hline Total & $\mathbf{8 7 7 , 8 2 0}$ & 140,850 & 20,135 & 716,835 \\
\hline \multicolumn{5}{|l|}{ Hill } \\
\hline Rice husks & 7,960 & 0 & 0 & 7,960 \\
\hline Rice straw & 37,770 & 0 & 4,910 & 32,860 \\
\hline Maize stalks & 30,100 & 30,100 & 0 & 0 \\
\hline Maize husks & 4,870 & 0 & 0 & 4,870 \\
\hline Maize cobs & 4,750 & 4,750 & 0 & 0 \\
\hline Wheat husks & 280 & 0 & 0 & 280 \\
\hline Wheat straw & 470 & 0 & 71 & 399 \\
\hline Millet husks & 430 & 0 & 0 & 430 \\
\hline Millet straw & 5,400 & 0 & 0 & 5,400 \\
\hline Total & 92,030 & 34,850 & 4,981 & 52,199 \\
\hline \multicolumn{5}{|l|}{ Mountain } \\
\hline Rice husks & 3,830 & 0 & 0 & 3,830 \\
\hline Rice straw & 18,220 & 0 & 3,827 & 14,393 \\
\hline Maize stalks & 4,570 & 4,570 & 0 & 0 \\
\hline Maize husks & 730 & 0 & 0 & 730 \\
\hline Maize cobs & 720 & 720 & 0 & 0 \\
\hline Wheat husks & 8,040 & 0 & 0 & 8,040 \\
\hline Wheat straw & 13,190 & 0 & 4,221 & 8,969 \\
\hline Millet husks & 90 & 0 & 0 & 90 \\
\hline Millet straw & 1,290 & 0 & 0 & 1,290 \\
\hline Barely straw & 1,130 & 0 & 170 & 960 \\
\hline Total & 51,810 & 5,290 & 8,218 & 38,302 \\
\hline
\end{tabular}

Non-dedicated fodder residues in the hill and mountain districts are not used for cooking regular meals; rather the households use them for fodder preparation, which generally takes place outside the house. Based on the net calorific value, the annual energy potential of all crop residues for the three districts was estimated (Table 6).

Table 6: Annual energy production potential of crop

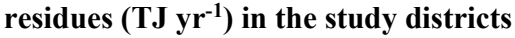

\begin{tabular}{lllll}
\hline $\begin{array}{l}\text { Crop } \\
\text { residue }\end{array}$ & $\begin{array}{l}\text { Net calorific } \\
\text { value }\left(\mathbf{M J ~ k g}^{-1}\right)\end{array}$ & $\begin{array}{l}\text { Lowl } \\
\text { and }\end{array}$ & Hill & $\begin{array}{l}\text { Mou } \\
\text { ntain }\end{array}$ \\
\hline Rice husks & 16.57 & 195 & 0.00 & 0.00 \\
Rice straw & 15.80 & 783 & 0.00 & 0.00 \\
Maize stalks & 15.44 & 818 & 465 & 71 \\
Maize cobs & 15.57 & 126 & 74 & 11 \\
Wheat husks & 17.46 & 120 & 0 & 0 \\
Wheat straw & 17.46 & 202 & 0 & 0 \\
\hline Annual potential & 2,244 & 539 & 82 \\
\hline
\end{tabular}

In per capita basis, the hill district shows the highest potential of crop residues for energy production due to the higher per capita production of maize (Table 7). As the maize stalks and cobs are non-dedicated fodder residues, they can be fully utilized for energy production. In the present context, although all maize cobs were utilized for energy production at the household level, this was not the case for maize stalks. Even the full utilization of crop residues in the region with the highest production of crop residues (hill district) contributes to only $31 \%$ of the total energy consumption (Table 7), and the contribution is negligible in the mountain district.

On the national level, only about $26 \%$ of crop residue production was found to have potential for energy generation ${ }^{3}$, which contradicts the earlier national assumption of $50 \%$ [20]. At present, the utilization of crop residues has the potential to replace 1.6 million $t$ of fuelwood, which is equivalent to $28 \%$ of the LPG consumption in $2014 / 15^{4}$.

\section{Conclusions and Recommendations}

The investigation of crop residues for energy production is critical to reduce the prevailing overexploitation especially of fuelwood in the hills and mountains where the use of crop residues is negligible. As the households in the lowland already consume all types of crop residues for energy production because of the fuelwood deficit there, the assessment of the use of crop residues for energy

\footnotetext{
${ }^{3}$ The estimation is based on national annual production data of rice $(5,047,047 \mathrm{t})$, maize $(2,283,222 \mathrm{t})$, wheat $(1,893,482 \mathrm{t})$, millet $(304,105 \mathrm{t})$ and barley $(34,824 \mathrm{t})$ as obtained from [30].

${ }^{4} 1 \mathrm{~kg}$ crop residues $=0.4 \mathrm{~kg}$ fuelwood $=0.017 \mathrm{~kg} L P G[30]$
} 
Table 7: Annual per capita energy supply potential of crop residues in the study districts

\begin{tabular}{|c|c|c|c|c|}
\hline \multirow[b]{2}{*}{ District } & \multirow[b]{2}{*}{ Population } & \multirow{2}{*}{$\begin{array}{l}\text { Energy consumption } \\
\left(\text { GJ } \text { capita }^{-1} \mathbf{y r}^{-1}\right) *\end{array}$} & \multicolumn{2}{|c|}{ Crops residue supply } \\
\hline & & & $\begin{array}{l}\text { Energy potential } \\
\left(\text { GJ } \text { capita }^{-1} \mathrm{yr}^{-1}\right)\end{array}$ & $\begin{array}{l}\% \text { share potential of total } \\
\text { energy consumption }\end{array}$ \\
\hline Lowland & 964,553 & 8.21 & 2.32 & 28 \\
\hline Hill & 167,771 & 10.34 & 3.21 & 31 \\
\hline Mountain & 195,207 & 11.78 & 0.41 & 3 \\
\hline
\end{tabular}

*Retrieved from [30]

production is extremely important in order to examine the possible consequences of other uses mainly for fodder. As this study evaluates the potential of crop residues for energy production by considering their different other uses under pragmatic conditions, the results are pertinent for further considerations. Crop residues in the hills have a potential to contribute significantly to total energy consumption whereas the contribution in the mountains is negligible.

The current trend of inefficient utilization of crop residues by direct burning for energy production needs to be modified by the introduction of modern and efficient technologies. Of various technologies, briquetting might be a promising energy technology for households. Given the significant potential energy contribution of crop residues in the hills, the local-level awareness and incentives programs for energy use of crop residues could reduce overexploitation of fuelwood. In the mountains, herbaceous materials and dung for energy production should be investigated to compensate the lower production of crop residues there.

\section{Acknowledgments}

This research work was financially supported by German Federal Ministry for Economic Cooperation and Development (BMZ) via DAAD scholarship program and by a grant from Dr. Hermann Eiselen Doctoral Programm of the Foundation fiat panis. The authors would like to acknowledge to those institutions. Similarly, we would also like to acknowledge Nepal Academy of Sciences and Technology (NAST) for providing laboratory facilities

\section{References}

[1] R. Lal, "World crop residues production and implications of its use as a biofuel.," Environ. Int., vol. 31, no. 4, pp. 575-84, May 2005.

[2] A. Koopmans and J. Koppejan, "Agricultural and forest residues-generation, utilization and availability," Pap.
Present. Reg. Consult. Mod. Appl. Biomass Energy, vol. 6, no. 10, 1997.

[3] UNEP, "Converting waste agricultural biomass into a resource: compendium of technologies," Osaka/Shiga, Japan, 2009.

[4] K. Kumar and K. M. Goh, "Crop Residues and Management Practices: Effects on Soil Quality, Soil Nitrogen Dynamics, Crop Yield, and Nitrogen Recovery," Adv. Agron., vol. 68, pp. 197-319, 1999.

[5] S. Andrews, "Crop residue removal for biomass energy production: Effects on soils and recommendations," 2006.

[6] J. F. Power, P. T. Koerner, J. W. Doran, and W. W. Wilhelm, "Residual effects of crop residues on grain production and selected soil properties," Soil Sci. Soc. Am. J., vol. 62, no. 5, pp. 1393-1397, 1998.

[7] D. R. Sumner, B. Doupnik, and M. G. Boosalis, "Effects of reduced tillage and multiple cropping on plant diseases," Annu. Rev. Phytopathol., vol. 19, no. 1, pp. $167-187,1981$

[8] B. Govaerts, M. Fuentes, M. Mezzalama, J. M. Nicol, J. Deckers, J. D. Etchevers, B. Figueroa-Sandoval, and K. D. Sayre, "Infiltration, soil moisture, root rot and nematode populations after 12 years of different tillage, residue and crop rotation managements," Soil Tillage Res., vol. 94, no. 1, pp. 209-219, May 2007.

[9] C. J. Green and A. M. Lackmer, "Residue decomposition effects on nitrogen availability to corn following corn or soybean," Soil Sci. Soc. Am. J., vol. 59, no. 4, 1995.

[10] V. Smil, “Crop Residues: Agriculture's Largest Harvest Crop residues incorporate more than half of the world's agricultural phytomass," Bioscience, vol. 4, no. April, pp. 299-308, 1999.

[11] A. Milhau and A. Fallot, "Assessing the potentials of agricultural residues for energy: What the CDM experience of India tells us about their availability," Energy Policy, vol. 58, pp. 391-402, Jul. 2013.

[12] F. R. Callé and F. Rosillo-Calle, The biomass assessment handbook: bioenergy for a sustainable environment. Earthscan, 2007.

[13] FAO, "BIOENERGY AND FOOD SECURITY RAPID 


\section{APPRAISAL (BEFS RA): CROP RESIDUES AND LIVESTOCK RESIDUES,” 2014.}

[14] M. Ilić, B. Grubor, and M. Tešić, "The state of biomass energy in Serbia," Therm. Sci., vol. 8, no. 2, pp. 5-20, 2004.

[15] X. Wang and R. Mendelsohn, "An economic analysis of using crop residues for energy in China," Environ. Dev. Econ., vol. 8, no. 03, p. 467, Jun. 2003.

[16] S. Sokhansanj, S. Mani, M. Stumborg, R. Samson, and J. Fenton, "Production and distribution of cereal straw on the Canadian Prairies," Can. Biosyst. Eng., vol. 48, no. 3 , 2006.

[17] MoAD, "Statistical Information on Nepalese Agriculture 2011/12," Kathmandu, 2012.

[18] D. Pariyar, "Country Pasture/Forage Resource Profiles," 2005. [Online]. Available: http://www.fao.org/ag/AGP/AGPC/doc/counprof/Nepal/n epal2.htm.

[19] P. Tulachan and A. Neupane, "Livestock in mixed farming systems of the Hindu Kush-Himalayas," in Trends and Sustainability, 1999, p. 116.

[20] WECS, “Energy Sector Synopsis Report 2010,” 2010.

[21] AEPC, "Final Report on Study on Feasibility and Market Identification of Densified Biomass Briquettes," Khumaltar, Lalitpur, 2014.

[22] CSMT, "Draft Report on Mitigation Assessment of Greenhouse Gases Emissions for Energy Sector in Nepal,' Kathmandu, Nepal, 1996.

[23] G. Shakya and I. Shakya, "Salient features of biomass briquetting in Nepal," Int. Energy J., vol. 3, no. 2, pp. 99109, 2002.

[24] J. Gerrard and R. Gardner, "Relationships Between Landsliding and Land Use in the Likhu Khola Drainage Basin, Middle Hills, Nepal," Mt. Res. Dev., vol. 22, no. 1, pp. 48-55, Feb. 2002.

[25] D. P. Sherchan, C. J. Pilbeam, and P. J. Gregory, "Response of wheat\&\#8211;rice and maize/millet systems to fertilizer and manure applications in the mid-hills of Nepal,” Exp. Agric., vol. 35, no. 01, pp. 1-13, 1999.

[26] N. R. Khanal and T. Watanabe, "Abandonment of agricultural land and its consequences," Mt. Res. Dev., vol. 26 , no. 1 , pp. $32-40,2006$.

[27] B. D. Regmi and M. A. Zoebisch, "Soil fertility status of Bari and Khet land in a small watershed of middle hill region of Nepal," Nepal Agric. Res. J., vol. 5, pp. 38-44, 2004.

[28] FAO, "Bioenergy and Food Security:The BEFS Analytical Framework," 2010.

[29] C. R. Upreti and B. K. Shrestha, "Nutrient contents of feeds and fodder in Nepal," 2006.

[30] N. P. Adhikari, "Spatial variation of biomass energy supply and demand in rural Nepal," University of Bonn, 2017.

[31] FAO, "Long-term scenarios of livestock-crop-land use interactions in developing countries," 1997.

[32] MoAD, "Statistical information on Nepalese Agriculture 2013/14," 2014. 